\title{
APSA Executive Director's Report, 2009
}

\author{
Michael Brintnall, American Political Science Association
}

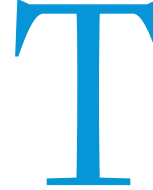

he Executive Director's Report is an annual report on the state and activities of the association, and for 2009 it is hard not to reach outside the literal bounds of the association to reflect on the discipline, the academy, and the economy as a whole. Simply put, the American Political Science Association has weathered the financial storms of the past year well, though we know as well that reverberations from the economic downtown will continue for some time, with the potential for a sustained period of change.

The association is in a sound position in the face of the economic downturn and the corresponding dislocations in many academic institutions. Membership shows only a small dip and annual meeting registrations were on target with our projections for a new, international, venue. Recent and projected budgets remain in balance with several conservative financial steps in place-as reported below in the finance report-but no significant reductions in programming. The program agenda remains vigorous.

The APSA Executive Director's Report is being published on a slighty new schedule this year to address association activities through the end of September 2009. Prior program years had ended in June. This timing is adjusted to conform to a new fiscal year for APSA that will run from October through September, which simplifies budgeting and financial management, predominantly because it brings annual meeting revenues and expenditures into the same fiscal time period.

This report begins with a note on two major issues emerging with the discipline and APSA's response, followed by an update on APSA initiatives and a report on the state of the association. In two salient issues for the discipline, attention in 2009 turned to the emerging academic employment situation and to sustaining public support for political science.

\section{STATE OF THE DISCIPLINE \\ Employment}

Meeting the immediate needs of new graduates for placement opportunities. As of this writing the outcome of the 2009 academic job market in political science for positions to begin in 2010 is not clear, though a sub- stantial drop-off in positions is obvious. By October 2009, listings for assistant professor job searches in the APSA employment newsletter was down by $50 \%$ from recent years. Listings in any year do not necessarily reflect positions eventually filled, so the placement outcomes may be better or worse than this, and we won't know these answers for a while.

There are a variety of informal steps that the academic community has explored for soft landings for new graduates not finding immediate positions. The American Council of Learned Societies has received funding to create 50 two-year teaching post-doctoral positions. And many colleges and universities have been taking steps to support new and imminent graduates for a longer period before they find placement.

Adjuncts and the Academic Workforce. Following a longer-term trend, higher education is increasingly relying on use of adjunct faculty and it is expected that academic institutions facing financial pressures to downsize will further turn to adjuncts to fill the gaps. Pay scales and opportunities for professional development are often quite limited, and the implications of these staffing models for teaching and learning are of concern. APSA has begun to monitor these conditions in political science in greater detail through our departmental survey. APSA also is a member of the Coalition for the Academic Workforce (http://www.academicworkforce.org), which is a loose alliance of learned societies focused on the situation of adjunct faculty in higher education. While other associations have taken individual positions regarding elements of the issue such as equitable pay, access to benefits and professional development, or employment stability, APSA has not yet taken a formal position on this issue.

\section{Research Support}

Minerva. In the spring of 2008, secretary of defense Robert Gates proposed the Minerva Research Initiative providing as much as $\$ 75$ million from Defense Department funds over five years to support social science research on areas of strategic importance to U.S. national security policy. After some deliberations, some of the funding was redirected to the National Science Foundation to administer and some was released as contracts by DoD itself.
The prospect raised many questions from the academic community, and it was posed as a matter of concern at the APSA General Membership Meeting in 2008. APSA subsequently wrote to NSF raising questions about transparency of the funding process and urging greater clarity in the role the DoD would play in reviews, with polite but little substantive response. The NSF program is independent of that administered by the Department of Defense, and is based on a solicitation NSF issued entitled "National Security Conflict and Cooperation." NSF has not yet received funds from Defense for this solicitation. The Social Science Research Council has sought to foster an academic discussion about Minerva wider than the question of funding integrity alone. Their papers are online at http://www.ssrc.org/ essays/minerva/. DoD and NSF awards have subsequently been made, and APSA will continue to monitor whether any issues of interference with academic freedom may emerge in the process.

While early discussed addressed the integrity (and desirability) of the Minerva process at all, a related lesson from this debate is evidence of deficiencies in the current state of knowledge exchange between academics and military officers engaged with relevant scholarship. The Minerva process suggests there is a frustration among some military officers with the conventional government contractors and their thinking, plus a realization that academia doesn't have the answers at hand either. A set of more dynamic opportunities for exchange between academic scholars and military officers may have benefits for both

National Science Foundation. On a separate, and puzzling track, given the signals from Minerva that NSF is a welcome home for political science research in the national interest, In early October 2009, APSA learned about a harmful Senate amendment (S.Amdt.2631) to the Commerce, Justice, and Science Appropriations bill (H.R.2847) that would prevent the National Science Foundation from funding political science research. APSA took direct steps to lobby on this issue to alert the Senate that this restriction of funds would prevent critical research on many pressing domestic and international issues. APSA members were also alerted and encouraged to respond. The Consortium of 
Social Science Associations played a lead role in responding to this amendment, and other social and behavioral science organizations, the American Council on Education, the American Association of Universities spoke out against it as well. The amendment failed, but its emergence is a clear alert that we must continue vigorously to express the value of our work. APSA will prepare a full report on its reaction to this event, and plans for promoting the public understanding of the political science discipline.

\section{UPDATE ON APSA INITIATIVES}

APSA maintains a very active program agenda across all dimensions of our agenda-research scholarship, professional development and support, teaching and learning, and public affairs. The following snapshots describe activity in many, though not certainly not all, of key program areas.

\section{Journals}

Perspectives. One of APSA's most distinctive ventures in recent years has been the establishment of a significant new journal in the field, Perspectives on Politics, and nothing signals its success more than showing a continued progression of distinguished editorships. In June 2009, editorial leadership passed from James Johnson and editorial offices at the University of Rochester to Jeffrey Isaac and Indiana University. Johnson had played a significant role in establishing the journal following its startup editorship.

Isaac has assumed editorial direction of the journal as a whole, as well as of the book reviews, which he had handled under Johnson's editorship since 2005. In his plans for the journal, Isaac intends to move further along the path of original intentions for the journal to be a "space for broad and synthetic discussion within the political science profession and between the profession and the broader scholarly and reading publics."

In Isaac's words: "Perspectives seeks to nurture a political science public sphere that transcends subfield and methodological boundaries and facilitates discussion of the big orienting questions at the heart of political science at its best-the foundations of political order and disorder; the productivity and destructiveness of organized violence; the relationship between politics, economics, and society; the distribution of inclusion and exclusion, power and vulnerability, as this relates to race, class, gender, ethnicity, and other identities; the dynamics of democratic politics and the forms of democratic citizenship; and the limits of the nation-state."

American Political Science Review. The Review in turn continues under the ambitious and experimental leadership of a broad editorial team centered at the University of California, Los Angeles, leaded by editor in chief Ronald Rogowski. In the face of unremitting submissions, 1,472 new articles submitted for review in the past two years, the Review continues to publish work of the highest distinction in the discipline, with the largest numbers in fields of comparative politics and normative theory. The editorial team also made strides in the last year in reducing turnaround and tightening publication deadlines, while still retaining an ambitious commitment to provide meaningful feedback to authors, accepted or rejected.

PS. The journal PS: Political Science and Politics, edited by APSA's deputy director Rob Hauck continues to offer symposia, articles, and teaching resources of great timeliness, high caliber, and active interest to political scientists members and the broader public. It also serves as a journal of record for activities of the association and the discipline, in tandem with APSA eNewsletters and Web site. $P S$ can be thought of as the association's original social networking tool, and it continues to be at the forefront of public attention to ongoing political science work, with frequent press references.

Organized Section Journals. While the three journals referenced above remain the core of APSA journals, the association is aligned far more diversely with scholarly publication through Organized Section journals as well. Fifteen APSA Organized Sections now have relationships with journals, either owning them directly (under APSA's corporate umbrella), having exclusive editorial control of journals owned by their publishers, or partnering with other institutions.

\section{Annual Meeting}

Boston 2008. Because of a change in the timing of this Executive Director's Report, two annual meetings have occurred since the last writing. The 104th APSA annual meeting convened in Boston, Massachusetts, August 28-31, 2008, with a recordbreaking number of 7,200 political scientists, academics from related fields, and publishers attending. Program chairs were Jane Junn, Rutgers University-New Brunswick, and Ed Keller, University of California, Los Angeles, and the schedule included more than 900 panel sessions, roundtables, and plenary addresses, organized around the theme "Categories and the Politics of Global Inequalities."

Toronto 2009. On the heels of a recordsetting 2008 annual meeting, APSA's 105th meeting in Toronto crossed another milestone, as our first meeting outside of the United States. While attendance did not match the Boston venue, over 6,ooo scholars participated, exceeding expectations for a cross-border venue in an economic downturn. This historic meeting was organized by program chairs Bruce Jentleson of Duke University and Simone Chambers of University of Toronto under the theme "Politics in Motion: Change and Complexity in the Contemporary Era." They asked scholars "to think about the pursuit of knowledge in a context of change and complexity as both a scholarly endeavor and for bringing that knowledge to bear on the crucial challenges that shape our contemporary era." The international venue was well received by members attending, and APSA will continue to consider siting future meetings in Canada.

We have continued our green meeting efforts through a significant reduction in the printing of the preliminary program and use of paper and vendors for APSA printed material that are certified by the Forest Stewardship Council (FSC).

A new "personal meeting scheduler" went online this summer for the Toronto meeting, allowing users to review the online program and build a personal calendar of items and activities of interest.

Siting and Engagement. As APSA meeting siting and planning goes forward, new policies are being implemented to address questions of how we select sites and how we engage with the communities in which we meet. One issue on the table had been questions about the appropriateness of Canada as a site because of Canadian and provincial law regarding hate speech and the prospect that implementation of hate speech laws might infringe academic freedom. APSA explored these issues in detail, and posted information on the APSA Web site (http:// www.apsanet.org/content_60741.cfm) for members to review. No issues emerged, as a practical matter, onsite.

A new APSA Committee on Siting and Engagement was named in the last following Council discussions about issues raised over the upcoming 2012 meeting in New Orleans. New Council policy calls both for engagement on issues in the state and locality of importance to the APSA community, and a new committee has been formed to oversee this. The committee includes members rec- 
Table 1

\section{Annual Meeting Registration}

\begin{tabular}{|c|c|c|c|}
\hline YEAR & ATTENDEES & LOCATION & in which we are going \\
\hline 1973 & 2,312 & New Orleans & develoning a strategy \\
\hline 1974 & 2,773 & Chicago & for a process of engage- \\
\hline 1975 & 2,478 & San Francisco & ment, beginning with \\
\hline 1976 & 2,295 & Chicago & the upcoming 2010 \\
\hline 1977 & 2,624 & Washington, D.C & \\
\hline
\end{tabular}

Teaching and Learning Conference

Baltimore. APSA's other major conference is the Annual Conference on Teaching and Learning in Political Science The Sixth Annual Teaching and Learning Conference took place in Baltimore, Maryland, February 6-8, 2009, with 239 attendees. This conference uses a working-group model with sustained participation in tracks for the length of the meeting. Track sessions are augmented with a variety of topical workshops.

Political scientists from around world took part in the Baltimore meeting: $47 \%$ of the attendees were university faculty, $30 \%$ were faculty at colleges, $9 \%$ came from community colleges, and $1 \%$ were high school teachers. The remainder of attendees were either graduate students, publishers, or individuals from the private sector. Forty-five attendees were first-time TLC participants, half had attended one TLC in the past, and others had attended more frequently.

Typical themes for the working-group tracks are Program Assessment; Civic Education; Teaching Research Methods;
Internationalizing the Curriculum; Simulations and Role Play; Diversity, Inclusiveness, and Equality; Professional Development and Graduate Education; and Core Curriculum/ General Education. For 2010, when the conference will meet in Philadelphia, two new tracks are proposed: Teaching Political Theory and Theories and Integrating Technology into the Classroom. There will also be one new workshop track: Strategies for Teaching and Community Colleges.

\section{APSA Connect}

Social Networking. APSA has sought from the start of Web-based communication to stay current with tested strategies, and a major new step in this arena has begun with the introduction of the APSA Connect social networking site. This resource integrates Web communication capacity, such as threaded list discussion, document sharing, and community group formation with the association's membership systems. One building block will be improved communications among formally organized entities, such as APSA Organized Sections and Committees. But significantly more powerful outcome will be the ability for members to post profiles of their professional status and interests, and to form informal public and private groups for discussion based on common themes. This is a major system development, integrated with APSA's membership data systems, and drawing on established third-party technology. We'll report in detail as this new capability develops.

\section{Department Programs}

Support for Department Chairs and Graduate Program Directors. In addition to individual member services, APSA has always provided support for academic departments, through the Departmental Services Program. Significant steps are underway to upgrade these efforts in support of academic departments and department chairs. Several listing sessions were held with department chairs at regional political science meetings during the year, and three sessions were organized for the annual meeting in Toronto: the regular workshop for chairs, a roundtable on external reviews, and a working session for graduate program directors.

One of the significant new steps has been a Conference for Department Chairs. This was aligned in 2009 with the Teaching and Learning Conference in Baltimore, and addressed themes of working with adjunct 
Figure 1

\section{Annual Meeting Registration (1973-2008)}

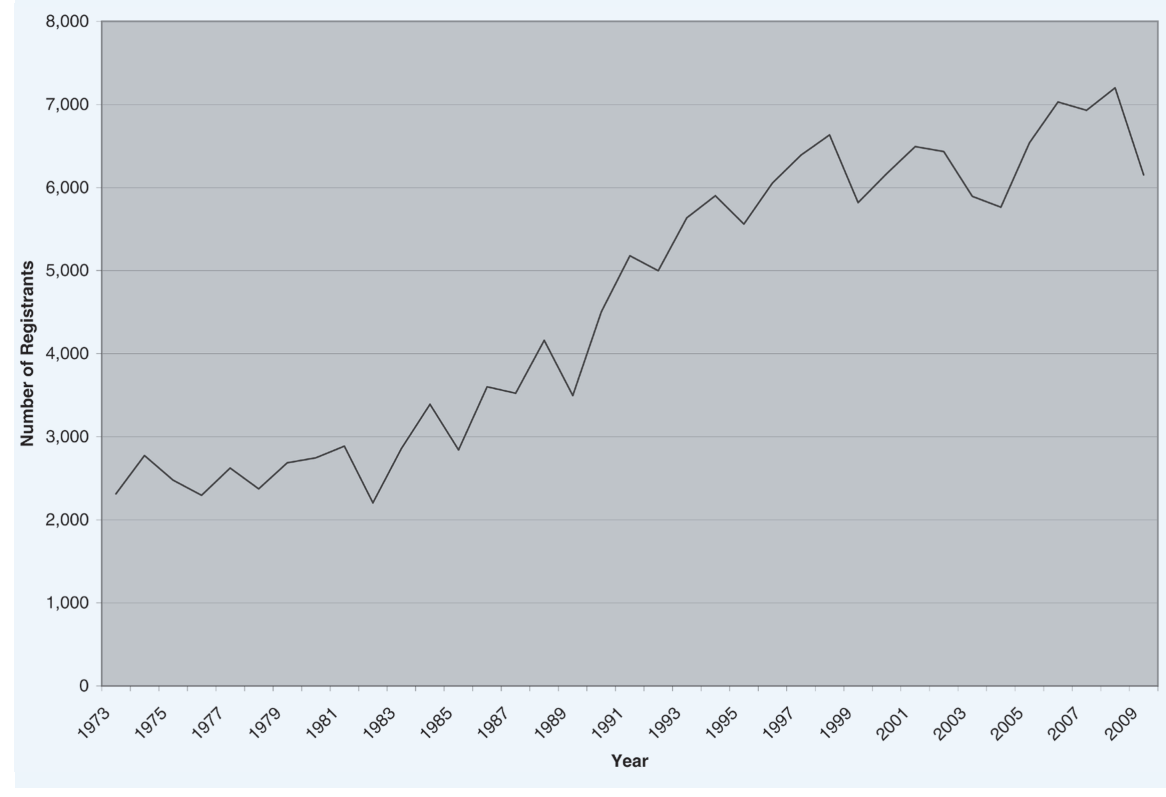

faculty, assessment, and pipeline programs for diversity in training and hiring. The conference will be moved to Washington, D.C., for 2010, covering legal issues for chairs and national policy in a period of hard times for higher education.

New departmental survey tools are now in the field on general characteristics of departments, placement, and, in the fall, enrollment levels. The survey tool includes an innovative benchmarking capability to allow departments to select a pool of comparable institutions for comparison, while protecting anonymity of responses.

\section{Centennial Center}

The Centennial Center, in its sixth year of operation, has hosted 17 scholars during 2009 in residencies from one week to one year. This year scholars have come from the United States, Brazil, the United Kingdom, Canada, Turkey, France, and Germany. The Centennial Endowments have distributed more than $\$ 9,000$ in funding. In the six years of operating more than $\$ 62,000$ has been given to scholars. In summer of 2009, the Centennial Center was at capacity hosting graduate-level students and professors completing research while their home universities were out of session.

\section{CFP}

Fellowship class. APSA's flagship Congressional Fellowship Program provides midcareer opportunities for scholars and other professionals to learn about the workings of Congress, and is widely regarded as the premier initiative in this area. Participants have an intensive orientation and then spend an academic year at work in congressional offices. Through endowments, APSA supports this program for political scientists and journalists, and manages it for professionals in other fields. In 2009, the program involved seven political scientists, three journalists, a scholar supported by the American Sociological Association, a Thai professional supported through the Asia Foundation, a Carl Albert Congressional Research Studies Center Fellow, a Native American Spirit Mountain Community Fund/Mark O. Hatfield Foundation fellow, two German fellows supported by the German Marshall Fund of the United States, ten fellows who are federal executives or foreign service officers, eight medical professionals from the Robert Wood Johnson Foundation program, and eight other Health and Aging Policy Fellows.

In the last instance the inclusion of Health and Aging Policy Fellows is a new addition to the program. The effort is supported by the Atlantic Philanthropies/Columbia University Medical School's Health Policy for the Aging Fellows. All of the ancillary programs both extend the objectives of the CFP and provide administrative fees to help support the entire effort.

Canada. In 2009 the U.S. State Department's Bureau of Western Hemisphere
Affairs also affirmed a commitment to provide added funding to support the threeplus-decades old Canada-US Parliamentary Exchange, as a component of the APSA Congressional Fellowship Program. State has also provided full funding, in the spirit of NAFTA, for two Mexican parliamentary staff (one an adviser to the president's office) to participate in the Ottawa visit.

\section{APSA Diversity Programs}

Minority Fellowships. In 2009, the APSA Minority Fellowship Program (MFP) celebrated its fortieth anniversary This milestone was celebrated at the 2009 annual meeting, with a roundtable featuring MFP alumni reflecting on their experiences and addressing future directions of the MFP. The MFP was established in 1969 as an effort to increase the number of minority scholars in the discipline, and has designated more than 500 fellows and contributed to the successful completion of doctoral political science programs for over 100 individuals.

Ralph Bunche Summer Institute. An important companion effort to the MFP is the Ralph Bunche Summer Institute (RBSI), which provides summer training and introduction to doctoral work for promising undergraduates from diverse backgrounds or with an interest in advancing diversity initiatives. The program operates at Duke University, under the direction of Dr. Paula D. McClain. In 2009, this program was awarded a renewed threeyear National Science Foundation Grant for continued operation at Duke. Securing permanent ongoing funding for the RBSI program is one of APSA's highest priorities.

\section{International Initiatives}

International Agenda. APSA has always held international collaboration as a high objective. Through the Targeted International Membership Program, and the initiatives in Canada with the annual meeting, our non-U.S. memberships are at an all-time high. APSA remains an active partner with the International Political Science Association, and participated in the successful IPSA World Congress in Santiago, Chile, in July of 2009. Other efforts include a joint research study with India involving U.S. and Indian scholars working collaboratively on a study of Tocquevillian democracy, and ongoing discussions at the World Bank to incorporate political scientists more frequently in World Bank country teams.

Africa Project. New priorities for APSA international initiatives include working with 
scholars in less resourced countries to support efforts in their regions, co-led with local senior scholars. The flagship effort under this approach is the Africa Workshops Project, supported by the Mellon Foundation. The activity involves summer workshops for junior Africa-based scholars, co-led by senior U.S.- and Africa-based scholars, and focused on basic research themes. The project held a highly successful workshop in summer of 2009 in Accra, Ghana, the Accra Workshop on Elections \& Democracy. The program was co-led by Dr. Daniel Smith (University of Florida, USA), Dr. Kevin Fridy (University of Tampa, USA), Dr. Beatrix Allah-Mensah (University of Ghana, Legon), and Dr. Ukoha Ukiwo (University of Port Harcourt, Nigeria) and was managed on site by Helena Saele from APSA's staff, and coordinated by Bahram Rajaee. Over its two summer workshops, APSA has now worked with 40 African scholars in political science, with ongoing support for their continued research.

The Japan-U.S. Friendship Commission. Our initiative with the Japan-U.S. Friendship Commission also continues. The commission has agreed to fund the sixth in a series of APSA Open Boundaries Workshops on the gender, politics, and policy in Japan and the United States. The series of workshops is organized around the theme of women and politics and began in 2000. It was hosted by Karen O'Connor and the Women and Politics Institute at American University. The 2010 APSA Open Boundary Workshop will focus on the theme of gender, politics, and policy: post-elections with sessions in Washington, D.C., and Washington College in Chestertown, Maryland. Seventeen Japanese and American scholars will be led by Julie Dolan of Macalester College, Melissa Deckman of Washington College, Misako Iwamoto of Mie University, and Tokuko Ogai of Tokyo City University and Ochanomizu University's Institute for Gender Studies.

\section{Task Forces}

Policy. In an effort to bring political science research to bear on important issues within society and the profession, APSA has supported annual task forces over the last seven years. The task forces have addressed a broad set of issues, ranging from economic inequality and American democracy to interdisciplinarity. The task forces are conceived as two-year projects to demonstrate the pubic relevance of political science research, though many have taken longer generating a variety of products including succinct public-oriented documents, lon- ger monographs, teaching resources, Web sites, and press releases.

Task forces have been underway on the following themes:

Task Force on Inequality and American Democracy. The first of APSA's public presence task forces, this initiative worked to share what political scientists know about the ways in which recent trends in inequalities impact democratic participation and governance in the United States. It was named by APSA president Theda Skocpol and chaired by Larry Jacobs.

Task Force on Political Science in the $21^{\text {st }}$ Century. The Task Force on Political Science in the 21st Century, co-chaired by Dr. Luis Fraga and Dr. Terri Givens, was named by APSA President Dianne Pinderhughes to explore ways in which the discipline itself needs to be shaped to be responsive to a changing society.

Task Force on Difference and Inequality in the Developing World. This task force, chaired by John Echeverri-Gent and named by APSA president Susanne Rudolph, has worked to assemble what political science knows about key global problems and find ways and means by which our scholarship might influence public opinion, shape discourse in the public sphere, and influence policy makers.

Task Force on Political Violence and Terror. The task force is chaired by Martha Crenshaw and named by APSA president Martha Levi. Its work is partially funded by the Harry Frank Guggenheim Foundation. It is working to assess the contribution of political science to our understanding of how trends in civil violence, including the ways in which states respond to and/or instigate violence, affect domestic and international political order.

Task Force on Religion and Democracy in the United States. The task force is chaired by Alan Wolfe and was named by APSA president Ira Katznelson. It is partially funded by the Russell Sage Foundation. Its work is to examine how relevant disciplinary knowledge can help Americans understand the role that religion plays in public life, and consider both the opportunities and dangers to democracy that flow from the presence of significant numbers of citizens who possess strong religious convictions.

Task Force on U.S. Standing in World Affairs. The task force is chaired by Jeffrey Legro and was named by APSA president Peter Katzenstein. It divided its work into three subgroups that examine U.S. standing in (1) international society and organizations, (2) other regions and countries, and (3) the
American polity.

Task Force on Interdisciplinarity. This task force, chaired by John Aldrich and named by APSA president Robert Axelrod, has taken a focused look at how interdisciplinary scholarship can be enabled and advanced by the academy, as a foundation for more effective public relevance and presence. The emphasis is on practical aspects of academic management of the interdisciplinary system.

\section{Engagement}

Partnerships. APSA's priorities are supported by a number of strong partnerships that we perhaps don't often report enough about. We have strong liaison connections in many areas-counterpart political science associations, the AAAS, area studies associations, etc.

Four associations form the core of our relationships with counterpart organizations. These key groups are the National Humanities Alliance, the Consortium of Social Science Associations, the American Council of Learned Societies, and the Coalition for International Education. APSA supports each of these organizations, in some cases, substantially. Each organization is extraordinarily lean and cost-effective.

NHA. The National Humanities Alliance is a broad coalition of academic associations, preservation groups, state humanities centers, and the like, committed to advocacy in support of humanities scholarship and funding, and to advancing the work of the National Endowment for the Humanities. NHA has been an active resource supporting the Humanities Indicators Project of the American Academy of Arts and Sciences. And NHA recently held its Advocacy Day, which brought scholars to Capitol Hill to advocate for better funding. Political science's own David Price (D-NC), is the chair of the House Humanities Caucus, and is bolstered by NHA in this role!

COSSA. The Consortium of Social Science Associations is a tight-knit group of the key social science associations, and is focused on advocacy for social, behavioral, and economic science funding at the National Science Foundation and the National Institutes of Health. COSSA makes it possible for us to meet regularly with a broad range of NSF staff, and keeps the spotlight on broadening levels of SBE support at the NSF. COSSA was the forum in which the American Association of Universities approached the social science community, on behalf of Secretary Gates from the Department of Defense, to open discussions about the direction and 
structure of Minerva research funding.

ACLS. The American Council of Learned Societies both sustains research funding opportunities across the humanities (much as SSRC has done in social science), and works hard to build community across the disciplines and specialty fields. Joseph Lane, Emory and Henry College, is APSA's delegate to ACLS, and has reported recently in $P S$ on activities.

CIE. The Coalition for International Education is a tightly focused coalition of higher education associations, student aid and study abroad groups, networks of overseas area-study centers, and disciplinary groups. CIE's primary role is advocacy for advancing international programs in the Higher Education Act, including support of overseas areastudy centers. CIE was a major voice in the efforts to keep politically intrusive litmus tests out of the Title VI centers. It worked, and CIE made a big difference in protecting that program. With a Carnegie grant, CIE is sponsoring a symposium on Capitol Hill in honor of the fortieth anniversary of Title VI. Senators Lugar (R-IN) and Dodd (D-CT) are sponsoring this event. CIE is backstopped by the American Council on Education (ACE), is guided by the lobbying shops of both ACE and the American Association of Universities, and is led by a part-time coordinator, Miriam Kazanzian.

Other Engagement. One of the threads of interest and activity within APSA and the political science community has been the idea of engagement, and the relationship between academic political science, professional careers, and the public. While engagement emerging out of discussions about annual meeting siting may be the most prominent engagement theme on many members' minds, our efforts are far broader. Important activities in the association addressing the discipline's engagement with broader communities include the following: Standing Committee on Civic Education Task Force, the task force initiative to express to broader publics what political science has to say in key global issues, a standing conference on teaching and learning (teaching being perhaps our foremost act of engagement), a broad definition and reach of the Congressional Fellowship Program, the Centennial Center in the APSA offices, the formation of the Perspectives journal with an eye to offering the perspectives of rich scholarship to matters of public importance, a robust media relations program to disseminate political science research, and much else.

STATE OF THE ASSOCIA-

\section{TION}

Overview. The state of the association is strong. Key indicators for our membership and operations are positive in the face of the economic downturn and the corresponding dislocations in many academic institutions. Membership is steady and annual meeting registrations are close to previous year's numbers and on target. We presume there will be some drop in departmental memberships, in paid job listings, and in journal advertising revenue, and have budgeted for these contingencies

\section{Treasurer's Report}

Change of Fiscal Year. The APSA

Council last year approved a change in our fiscal year end from June 30 to September 30. This allows APSA to bring the revenue and expense streams for the annual meeting into the same fiscal year, simplify budgeting, and reduce accounting steps. It also aligns budget approvals more effectively with the Council meeting. To effect the change, APSA has operated with a three-month fiscal "year" from JuneSeptember 2009 and is filing an annual federal 990 tax return for the year ending June 2009, then a short year 990 return for the three-month "tax year" of July, August, and September 2009; and then the regular 12-month 990 return for the new 2010 fiscal year. There will be one 15-month audit for June 2008 through September 2009. 2008-2009 Balances. Operations for the 15 -month
Table 2

Market Value of APSA Funds, 1990-2008

\begin{tabular}{|c|c|c|}
\hline YEAR & $\begin{array}{l}\text { TRUST AND } \\
\text { DEVELOPMENT AND } \\
\text { CENTENNIAL FUNDS } \\
\text { (\$) }\end{array}$ & $\begin{array}{l}\text { CONGRESSIONAL } \\
\text { FELLOWSHIP AND } \\
\text { ENDOWED AWARD } \\
\text { FUNDS (\$) }\end{array}$ \\
\hline 1990 & $1,630,718$ & 419,012 \\
\hline 1991 & $1,555,574$ & $5,452,252$ \\
\hline 1992 & $1,905,090$ & $6,188,105$ \\
\hline 1993 & $2,118,787$ & $6,847,760$ \\
\hline 1994 & $2,190,976$ & $7,218,462$ \\
\hline 1995 & $2,807,182$ & $7,774,290$ \\
\hline 1996 & $3,284,013$ & $9,442,658$ \\
\hline 1997 & $4,283,425$ & $10,624,573$ \\
\hline 1998 & $5,965,087$ & $12,656,326$ \\
\hline 1999 & $6,984,978$ & $14,166,705$ \\
\hline 2000 & $8,137,173$ & $16,597,076$ \\
\hline 2001 & $7,466,348$ & $13,450,477$ \\
\hline 2002 & $6,731,050$ & $10,711,526$ \\
\hline 2003 & $7,596,378$ & $9,394,547$ \\
\hline 2004 & $9,335,566$ & $11,030,386$ \\
\hline 2005 & $9,895,713$ & $11,372,981$ \\
\hline 2006 & $10,909,085$ & $12,179,122$ \\
\hline 2007 & $12,549,503$ & $14,122,046$ \\
\hline 2008 & $10,980,994$ & $12,281,375$ \\
\hline 2009 & $7,831,822$ & $8,592,302$ \\
\hline
\end{tabular}

Table 3

Operating Budget 1991-2008: A Multi-Year Perspective

$\begin{array}{llll}\text { YEAR } & \text { INCOME } \mathbf{( \$ )} & \begin{array}{l}\text { EXPENDITURES } \\ \mathbf{( \$ )}\end{array} & \begin{array}{l}\text { SURPLUS } \\ \mathbf{( \$ )}\end{array} \\ 1987-88 & 1,637,637 & 1,563,252 & 74,385 \\ 1988-89 & 1,847,151 & 1,731,248 & 115,903 \\ 1989-90 & 1,891,773 & 1,871,302 & 20,471 \\ 1990-91 & 2,158,118 & 2,133,524 & 24,594 \\ 1991-92 & 2,256,647 & 2,199,632 & 57,015 \\ 1992-93 & 2,290,313 & 2,202,419 & 87,894 \\ 1993-94 & 2,574,436 & 2,294,128 & 280,308 \\ 1994-95 & 2,734,375 & 2,524,669 & 209,712 \\ 1995-96 & 2,822,154 & 2,590,227 & 231,927 \\ 1996-97 & 2,979,645 & 2,793,237 & 186,608 \\ 1997-98 & 3,068,237 & 2,981,914 & 86,323 \\ 1998-99 & 3,150,001 & 3,086,546 & 63,456 \\ 1999-00 & 3,395,355 & 3,224,919 & 170,436 \\ 2000-01 & 3,545,669 & 3,351,744 & 193,925 \\ 2001-02 & 3,621,269 & 3,447,455 & 173,813 \\ 2002-03 & 3,707,125 & 3,700,939 & 46,186 \\ 2003-04 & 4,026,806 & 4,028,780 & (1,974) \\ 2004-05 & 4,235,396 & 4,228,506 & 6,890 \\ 2005-06 & 4,516,090 & 4,333,740 & 182,350 \\ 2006-07 & 4,645,585 & 4,549,021 & 96,564 \\ 2007-08 & 4,760,164 & 4,826,910 & (66,746)\end{array}$




\section{Table 4}

\section{Operating revenue trends, 2004-09}

\begin{tabular}{lccccc} 
& $\mathbf{2 0 0 4 - 0 5}$ & $\mathbf{2 0 0 5 - 0 6}$ & $\mathbf{2 0 0 6 - 0 7}$ & $\mathbf{2 0 0 7 - 0 8}$ & $\mathbf{2 0 0 8 - 0 9}$ \\
\hline Individual memberships & $\$ 1,278,155$ & $\mathbf{\$ 1 , 3 1 9 , 9 6 8}$ & $\mathbf{\$ 1 , 3 9 4 , 7 3 4}$ & $\mathbf{\$ 1 , 4 1 7 , 2 9 3}$ & $\$ 1,543,079$ \\
\hline Institutional memberships & - & - & - & - & - \\
\hline Administrative & 59,434 & 63,218 & 61,666 & 73,794 & 69,731 \\
\hline Annual meeting registration/other & 564,353 & 682,393 & 788,138 & 803,053 & 939,461 \\
\hline Annual meeting advertising and exhibits & 369,113 & 328,814 & 389,870 & 361,578 & 364,923 \\
\hline Teaching and Learning Conference & 36,910 & 55,760 & 65,605 & 79,275 & 54,860 \\
\hline Dividends, interest, and draws & 236,021 & 441,511 & 163,891 & 140,528 & 75,626 \\
\hline Journals, sales, and publications & 849,367 & 922,122 & 986,903 & $1,046,199$ & $1,124,079$ \\
\hline Departmental services and eJobs & 313,088 & 355,571 & 420,823 & 470,802 & 494,230 \\
\hline Centennial Center & 171,790 & 23,400 & 23,091 & 35,780 & 24,070 \\
\hline Other (section dues, rental income, etc.) & 357,164 & 323,333 & 350,865 & 331,682 & 381,929 \\
\hline Total revenue* & $4,235,395$ & $4,516,090$ & $4,645,586$ & $4,760,164$ & $5,071,986$ \\
\hline
\end{tabular}

*Does not show budgeted revenue draw from endowment.

\section{Table 5}

\section{Operating expenditure trends, 2004-09}

\begin{tabular}{lccccc} 
& $\mathbf{2 0 0 4 - 0 5}$ & $\mathbf{2 0 0 5 - 0 6}$ & $\mathbf{2 0 0 6 - 0 7}$ & $\mathbf{2 0 0 7 - 0 8}$ & $\mathbf{2 0 0 8 - 0 9}$ \\
\hline Journals, publications, and Web & $\$ 1,008,004$ & $\$ 944,591$ & $\$ 1,037,408$ & $\$ 1,155,131$ & $\$ 1,101,598$ \\
\hline Annual meeting & 539,795 & 575,888 & 693,462 & 721,440 & 909,711 \\
\hline Teaching and Learning Conference & 121,640 & 145,970 & 143,953 & 168,189 & 153,193 \\
\hline Programs and projects & $1,164,335$ & $1,234,340$ & $1,169,089$ & $1,208,658$ & $1,267,111$ \\
\hline Governance & 265,915 & 301,129 & 263,006 & 348,452 & 348,750 \\
\hline Membership, business office, and sales & 477,037 & 507,689 & 568,459 & 558,233 & 634,466 \\
\hline General operating and building & 651,781 & 624,133 & 673,644 & 666,807 & 738,188 \\
\hline Total expense & $4,228,507$ & $4,333,740$ & $4,549,021$ & $4,826,910$ & $5,153,018$ \\
\hline
\end{tabular}

fiscal year ending September 2009 concluded positively relative to budget. Direct operations-prior to taking a budgeted draw from endowment-ended with a net deficit of $\$ 19,064$ in the operating budget, before turning to the budgeted draw from the Trust Fund (endowment) for operations of $\$ 213,200$. We have nevertheless moved the budgeted draw from the trust pool of investments to the Working Capital funds to add to cash reserves.

The 2009-2010 budget is in balance, incorporating several conservative budgeting assumptions approved by the Council-that the draw from the Trust Fund (endowment) for operations based on the lesser of $4.5 \%$ of the most recent annual value of the fund and the three-year moving average; that we budget an "allocation against revenue declines" of roughly $5 \%$ of membership dues, to cush- ion against revenue declines that we have not been able to anticipate specifically; and that we adopt a moratorium on committee travel for two years. Staff salaries have also been limited to a $1 \%$ COLA for the 18 -month period.

Audit. The FY 2008 audit is a clean audit. The auditor's management letter notes that there were delays in the 2008 audit tied to backups in the APSA's financial processinga situation APSA has already rectified by allocation of a staffline from elsewhere in the office (following a retirement) to finances and the hiring last year of a staff accountant.

The management letter also addresses ways that APSA's organized sections be recognized in the audit, noting that section financial operations are managed by independent treasurers though the tax ID remains APSA's. We are now getting legal advice on how to approach this, and will report to the Council in spring 2010.

Additionally the management letter points to a raft of new national accounting standards that will require our attention. None appears at the outset to raise difficulties for us, but we will track them all carefully. A major change will be the requirements for the new federal tax form 990. This will call for more review from the Council, for which the new Council Finance Committee will take the lead.

Trust and Development. The APSA Trust and Development Board has been entrusted by the association with the investment of trust, endowment, and other funds, and, with appropriate professional advice, makes investment decisions for these funds. Two are trust funds from which limited draws are made: a general trust pool that holds funds for general "endowment," awards, Centennial Center, and so forth, and the other for the Congressional Fellowship Program. The other main fund is that for operating reserves. The two trust funds are invested for long-term growth, benchmarked against the Russell 3000 and S\&P 500 indexes, and have largely tracked, and modestly exceeded, those indexes in the downturns and recent moves of the markets upward. Operating reserves are invested in fixed-income accounts with an eye to protecting principal. APSA's trust funds have of course dropped in value in line with the equities market. Fund levels at the close of the extended fiscal year in September 2009 (after moving the budgeted drawdowns to operating reserves, as discussed above) are off of summer 2008 levels by $23 \%$, consistent with relevant indexes.

The Trust and Development Board oversaw a major transition in the structure of APSA portfolios this year (though consistent with previous investment philosophy). After an independent RFP process, APSA 
selected Bogdahn Associations as a new investment advisor, and the converted all individual equity holdings to a small number of exchange traded funds (ETFs). This transition is complete. The overall coverage of sectors remains about the same, and these funds are exceeding the standard benchmarks for our investments.

The board is now in discussions with our investment manager about overall risk profiles for the funds, and in particular for adopting ways to regroup our investment funds into portfolios with different risk profiles-that is, to move funds with expected standard draw downs into a portfolio that is investment for greater stability of principal, and retain those funds for which our programming can adjust to swings in principal portfolios focused for growth.

The board also recognized that, in certain extreme circumstances, investment decisions may be required much more rapidly than routine board deliberation would allow. In such circumstances, the board has delegated to the APSA executive director (or, in his or her absence, to another APSA officer as identified in the policy) authority to act to protect APSA investments, following predetermined investment profiles.

Table 6

APSA Members, 1974-2009

\begin{tabular}{|c|c|c|c|c|c|c|c|c|}
\hline YEAR & REGULAR & UNEMPLOYED & ASSOCIATE & RETIRED & LIFE & FAMILY & STUDENTS & TOTAL INDIVIDUAL \\
\hline 1974 & 7,793 & & & 217 & 101 & 137 & 4,006 & 12,254 \\
\hline 1975 & 7,335 & & & 206 & 100 & 149 & 3,912 & 11,702 \\
\hline 1976 & 7,428 & & & 245 & 96 & 134 & 3,603 & 11,506 \\
\hline 1977 & 7,228 & & & 270 & 95 & 142 & 3,076 & 10,811 \\
\hline 1978 & 7,094 & & & 301 & 97 & 154 & 2,655 & 10,301 \\
\hline 1979 & 6,845 & & & 310 & 91 & 148 & 2,335 & 9,729 \\
\hline 1980 & 6,592 & & & 344 & 91 & 135 & 2,159 & 9,321 \\
\hline 1981 & 6,423 & & & 349 & 92 & 129 & 1,901 & 8,894 \\
\hline 1982 & 5,838 & & & 388 & 97 & 134 & 1,984 & 8,441 \\
\hline 1983 & 5,764 & & & 382 & 104 & 130 & 2,068 & 8,448 \\
\hline 1984 & 5,891 & & & 378 & 111 & 151 & 2,511 & 9,042 \\
\hline 1985 & 5,879 & & 106 & 411 & 116 & 166 & 2,595 & 9,273 \\
\hline 1986 & 6,009 & & 145 & 432 & 117 & 173 & 2,589 & 9,465 \\
\hline 1987 & 5,913 & & 154 & 439 & 127 & 202 & 2,775 & 9,610 \\
\hline 1988 & 6,171 & & 173 & 450 & 129 & 186 & 2,728 & 9,837 \\
\hline 1989 & 6,445 & & 249 & 489 & 166 & 192 & 3,054 & 10,595 \\
\hline 1990 & 6,708 & & 258 & 488 & 163 & 180 & 3,436 & 11,233 \\
\hline 1991 & 6,967 & & 266 & 519 & 160 & 199 & 3,656 & 11,767 \\
\hline 1992 & 7,046 & & 279 & 557 & 159 & 182 & 3,740 & 11,963 \\
\hline 1993 & 7,061 & & 291 & 573 & 157 & 194 & 3,979 & 12,255 \\
\hline 1994 & 7,505 & & 343 & 593 & 159 & 195 & 4,121 & 12,916 \\
\hline 1995 & 7,654 & & 340 & 623 & 164 & 205 & 4,750 & 13,736 \\
\hline 1996 & 7,349 & & 323 & 596 & 168 & 210 & 4,618 & 13,264 \\
\hline 1997 & 7,808 & 82 & 429 & 625 & 167 & 218 & 4,611 & 13,940 \\
\hline 1998 & 7,464 & 226 & 400 & 607 & 165 & 206 & 4,428 & 13,496 \\
\hline 1999 & 7,247 & 248 & 412 & 590 & 163 & 191 & 3,981 & 12,832 \\
\hline 2000 & 7,454 & 247 & 415 & 617 & 164 & 196 & 4,065 & 13,158 \\
\hline 2001 & 7,477 & 229 & 487 & 614 & 163 & 203 & 3,997 & 13,170 \\
\hline 2002 & 7,599 & 276 & 450 & 631 & 163 & 188 & 4,357 & 13,664 \\
\hline 2003 & 7,703 & 254 & 443 & 643 & 165 & 204 & 4,878 & 14,290 \\
\hline 2004 & 7,832 & 300 & 374 & 577 & 156 & 160 & 4,755 & 14,899 \\
\hline 2005 & 7,826 & 256 & 455 & 591 & 160 & 160 & 4,802 & 14,935 \\
\hline 2006 & 7,358 & 224 & 567 & 580 & 163 & 169 & 4,939 & 14,329 \\
\hline 2007 & 8,013 & 225 & 598 & 594 & 180 & 174 & 4,829 & 14,613 \\
\hline 2008 & 8,130 & 249 & 583 & 583 & 191 & 170 & 4,786 & 14,692 \\
\hline 2009 & 7,871 & 293 & 569 & 568 & 201 & 158 & 4,626 & 14,286 \\
\hline
\end{tabular}


Table 7

\section{Organized Section Membership}

As of December 2009

\section{ORGANIZED SECTION}

Federalism and Intergovernmental Relations

\begin{tabular}{lc}
\hline Law and Courts & 744 \\
\hline Legislative Studies & 573 \\
\hline Public Policy & 972 \\
\hline Political Organizations and Parties & 526 \\
\hline Public Administration & 497 \\
\hline Conflict Processes & 423 \\
\hline Representation and Electoral Politics & 311 \\
\hline Presidency and Research Group & 362 \\
\hline Political Methodology & 1,010 \\
\hline Religion and Politics & 575 \\
\hline Urban Politics & 368 \\
\hline
\end{tabular}

Science, Technology, and Environmen- $\quad 330$ tal Politics

Women and Politics 634

Foundations of Political Theory 726

Information Technology and Politics 355

Informational Security and Arms Con- 552 trol

\begin{tabular}{ll}
\hline Comparative Politics & 1,512 \\
\hline European Politics and Society & 466 \\
\hline State Politics and Policy & 457 \\
\hline Political Communication & 432 \\
\hline Politics and History & 616 \\
\hline Political Economy & 625 \\
\hline New Political Science & 558
\end{tabular}

Political Psychology $\quad 419$

Political Science Education 396

Politics, Literature, and Film 334

Foreign Policy 606

Elections, Public Opinion, and Voting 861

Behavior

\begin{tabular}{lc}
\hline Race, Ethnicity, and Politics & 541 \\
\hline International Politics and History & 399 \\
\hline Comparative Democratization & 622 \\
\hline Human Rights & 353 \\
\hline Qualitative Methods & 907 \\
\hline Sexuality and Politics & 221 \\
\hline Health Politics and Policy & 265 \\
\hline Canadian Politics & 148 \\
\hline Political Networks & 42 \\
\hline Total & 20,102
\end{tabular}

\section{Facilities}

1527 New Hampshire Avenue. The association's headquarters building at 1527 New Hampshire Avenue in Washington remains one of its most important assets. We have continued to work to maintain and upgrade the building, including work over the last several years to repaint the exterior, upgrade electrical panels (this will make possible future upgrades to heating and cooling, as well as provide greater general safety), configure office space more efficiently, and replace some flooring. Recent initiatives to install storm windows throughout the building and install efficient lighting has reduced electrical costs by about $\$ 7,000$ per year and will recover the installation costs several years in advance of the original estimate of a decade or so. Both to coordinate our own operations more effectively and to maximize revenue possibilities, we have consolidated APSA offices on the first three floors, along with the Centennial Center, and now fully lease the upper two floors.

152818 th Street. There is a new tenant for our second building on 18th StreetThe School for Ethics and Global Leadership (SEGL). This is a new program that has accepted its first class of 35 high school students for a Washington semester this fall. The program has an international relations focus and will be using the resources of the city to add to the conventional junior year curriculum. Most of the students will be coming from a broad range of private schools throughout the country. SEGL has made significant investment in the building for the period of their lease.

Organized Sections. APSA's organized sections continue to be a mainstay of the association. There are 38 organized sections and over half of all APSA members belong to at least one of them. Sections have the lead in structuring and organizing much of our annual meeting, and many now also manage and distribute journals in their fields. Three new sections have organized recently, Health Politics and Policy, Canadian Politics, and Political Networks

\section{CONCLUSION}

In difficult times for the academy and the economy, APSA remains in sound shape and is maintaining an active agenda for research scholarship, for professional development, for teaching and learning in political science, and for public engagement. We can expect hard times in higher education for some time to come. Building on the foresight of our predecessors, who have built APSA with solid base of resources, and on the commitment and public spirit of our members, the association is in a strong position to move forward. 